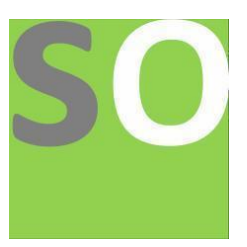

Article title: Removal of Heavy Metal using Non-ionic Surfactant: A Review

Authors: Felicia Alice Bayi[1], Amira Satirawaty Mohamed Pauzan[2]

Affiliations: Faculty of Resource Science and Technology, Universiti Malaysia Sarawak, 94300 Kota Samarahan, Sarawak, Malaysia.[1]

Orcid ids: 0000-0002-1768-7174[1], 0000-0002-2501-3364[2]

Contact e-mail: feliciaalicebayi@gmail.com

License information: This work has been published open access under Creative Commons Attribution License http://creativecommons.org/licenses/by/4.0/, which permits unrestricted use, distribution, and reproduction in any medium, provided the original work is properly cited. Conditions, terms of use and publishing policy can be found at https://www.scienceopen.com/.

Preprint statement: This article is a preprint and has not been peer-reviewed, under consideration and submitted to ScienceOpen Preprints for open peer review.

DOI: 10.14293/S2199-1006.1.SOR-.PPXWFE7.v1

Preprint first posted online: 04 October 2021

Keywords: heavy metal, non-ionic surfactant, cloud point extraction, soil washing 


\title{
Removal of Heavy Metal using Non-ionic Surfactant: A Review
}

\author{
Felicia Alice Bayi and Amira Satirawaty Mohamed Pauzan
}

Faculty of Resource Science and Technology, Universiti Malaysia Sarawak, 94300 Kota Samarahan, Sarawak, Malaysia.

\begin{abstract}
In emerging countries, heavy metal contamination is becoming more of a problem. Because of poor water and wastewater treatment, as well as increased industrial activities, heavy metal contamination in rivers, lakes, and other water sources has increased in developing countries. Non-ionic surfactants like Triton X-100 and Triton X-114 have been widely utilized to remove heavy metals from water, soil, and sediments via cloud point extraction and soil washing. The effectiveness of non-ionic surfactant to remove heavy metal was determined by the study of effect of the parameters which are $\mathrm{pH}$, surfactant concentration, temperature, and presence of natural organic matter (NOM). Based on the overall study, non-ionic surfactant efficiency in removing heavy metals is strongly reliant on water and soil quality parameters such as $\mathrm{pH}$, surfactant concentration, and temperature, as well as the surfactant's characteristics.
\end{abstract}

Keywords: heavy metal, non-ionic surfactant, cloud point extraction, soil washing

\section{Introduction}

\subsection{Research Background}

Heavy metal contamination is becoming more of a problem in developing countries. As a result of poor water and wastewater treatment, as well as increased industrial activities, heavy metal contamination in rivers, lakes, and other water sources has increased in developing countries (Joseph et al., 2019). Heavy metals are a prevalent contaminant found in both the soil and the water. $\mathrm{Ni}, \mathrm{Pb}, \mathrm{Zn}, \mathrm{Cd}, \mathrm{Cr}$, and $\mathrm{Cu}$ are the most common metals that pollute soil, all of which have a significant impact on organic matter, biochemistry, soil biology, clay content, and $\mathrm{pH}$. They have an indirect effect on soil enzymatic performance because they affect the microbial community which are responsible for enzyme production (Jaiswal et al., 2018).

As a result, there are a few methods for removing heavy metals from water and soil, such as the soil washing procedure for the soil and cloud point extraction for heavy metal removal from water. Surfactants are essential reagents in the cloud point extraction and soil washing 
processes, with non-ionic surfactants being the most commonly used. They are soluble and have a low ionisation level. Triton X-100 (polyoxyethylene-9.5-octylphenoxy ether) and Triton X-114 (polyoxyethylene-9.5-octylphenoxy ether) are two non-ionic surfactants extensively utilised (polyoxyethylene-9.5-octylphenoxy ether) (Mortada, 2020). They are necessary for the formation of micelles, which capture the separated material.

Cloud point extraction (CPE) is a non-hazardous approach for pre-concentrating and separating a wide range of analytes that outperforms traditional liquid-liquid extraction. The process is simple, rapid, low-cost, and precise. Because it employs no or extremely few toxic organic solvents, it is referred to as a "green" extraction process. The traditional CPE technique relies on non-ionic surfactants' ability to form micelles in aqueous media when heated above a certain temperature (known as the cloud point or cloud temperature) or when salt is introduced (salting-out phenomenon) (Mortada, 2020).

Soil washing is an ex-situ treatment that removes contaminants from soil through two processes: physical separation and chemical leaching using aqueous solutions. Surfactant-aided soil washing is one of the most promising soil remediation processes for heavy metalcontaminated samples. Surfactant-based soil washing has been proven to be a cost-effective remediation approach (Torres et al., 2005).

In this paper, the effectiveness of non-ionic surfactants for heavy metal removal is evaluated using a set of parameters, including the effects of $\mathrm{pH}$, temperature, surfactant concentration, and natural organic matter (NOM).

\subsection{Problem Statement}

Surfactant biodegradability and mildness, pollution control in industrial processes, and customer desire for practical and environmentally acceptable green solutions are among the main concerns in the surfactant industries (Lee et al., 2016). Furthermore, the toxicity of the surfactant and its likely breakdown products is one of the most important variables for selecting a surfactant for soil clean-up. The use of surfactants may lead to negative consequences such as depletion of minerals or oxygen, toxicity of surfactant intermediates, which are typically more hazardous than the parent molecules, or preferential breakdown of the surfactant, which slows pollutant degradation. Furthermore, the surfactant's breakdown will limit any bioavailability-enhancing effects. 


\subsection{Research Objectives}

The objectives of this review paper are to:

i) study the soil and water properties on non-ionic surfactants and

ii) investigate the efficiency of non-ionic surfactant for the removal of heavy metals in water and soil.

\section{Heavy Metals}

Heavy metal contamination is becoming more of a problem in developing countries. In undeveloped countries, where communities lack the capacity to appropriately treat contaminated water or access to clean drinking water infrastructure capable of supplying water to their homes, rising pollution has a particularly detrimental impact. According to the World Health Organization (WHO), 844 million people lack access to safe drinking water, and 230 million people spend more than 30 minutes each day collecting water from a better water source, such as piped water, boreholes, protected wells and springs, rainwater, and delivered water (Herschy, 2012). People can be affected by polluted water sources due to pathogen or toxic chemical exposure from dirty water irrigation, aquatic species intake of toxins, or recreational use of contaminated surface water (Joseph et al., 2019).

Heavy metals exist in various concentrations in soils, water, sediments, and plants. Because of the nature of the interactions that occur in this natural system, chemicals such as heavy metals that are released into the environment via one route may spread to many environmental components. Heavy metals can interact with natural substances chemically or physically, affecting their forms of presence in the environment.

\subsection{Heavy Metals in Soil}

Soil is a key reservoir for pollutants because of its propensity to bind different chemicals. These compounds can exist in several forms in soil, and they are fixed to soil particles by a range of pressures. It's vital to investigate these interactions since the way chemicals are stored in the environment can have a big impact on their toxicity. Heavy metal sorption in soil is influenced by several factors. Introduced compounds, such as heavy metal ions, can be immobilized by soil. Sorption parameters, which are determined by soil physicochemical parameters such as 
the quantity of clay and organic fraction, water content, $\mathrm{pH}$, soil temperature, and the properties of each metal ion, are responsible for the majority of xenobiotic immobilization.

Depending on the underlying geological foundation and current or previously existing anthropogenic and natural activity, many soils contain a wide range of heavy metals in various concentrations. Heavy metal pollution is most commonly caused by various metals such as lead $(\mathrm{Pb})$, nickel $(\mathrm{Ni})$, cadmium $(\mathrm{Cd})$, zinc $(\mathrm{Zn})$, chromium $(\mathrm{Cr})$, and copper $(\mathrm{Cu})$, ). Heavy metals including magnesium $(\mathrm{Mg})$, calcium $(\mathrm{Ca})$, iron $(\mathrm{Fe})$, and zinc $(\mathrm{Zn})$ are regarded to be important for humans and are suggested in the diet for their health advantages. (Jaiswal et al., 2018). Metal transport is influenced by the physical and chemical features of the soil, including soil organic matter concentration, clay fraction content, mineralogical composition, $\mathrm{pH}$, and other elements that contribute to the soil's binding ability. The qualities of soil may vary as a result of climate change, but they are most likely to alter as a result of human activities (Dube et al., 2001).

\subsection{Heavy Metals in Water}

Water is one of the most important resources. The importance of water resources, particularly surface waterways, in satisfying the needs of humans, animals, and businesses highlights the necessity to keep them clean. Rivers are essential water resources for human survival, not just for drinking water but also for sanitation and hygiene. Drinking contaminated water causes diarrhoea, and untreated excrement contaminates groundwater and surface waters that are utilised for drinking, irrigation, bathing, and residential purposes. Heavy metals and other biological and chemical pollutants enter the water through urban, industrial, and agricultural waste. Despite the fact that several of these metals are required micronutrients, their high concentrations in the food chain can produce toxicity and environmental effects, putting aquatic environments and users at risk (Shanbehzadeh et al., 2014).

\section{Surfactant}

Surfactant can have a significant impact on the adsorption behaviour of ion exchangers. In the presence of surfactants, the charge density of the interface effects the adsorption of metal ions on the exchanger surface (Varshney et al., 2007). Examine surfactant effectiveness, pricing, public and regulatory perception, biodegradability and breakdown products, toxicity to 
humans, animals, and plants, and recycling ability when selecting surfactants. The surfactants are effective in removing pollutants, which is the primary concern. (Mulligan et al., 2001).

Low toxicity, biodegradability, low soil adsorption, low soil dispersion, solubility at groundwater temperatures, effectiveness at concentrations less than $3 \%$, low surface tensions, and low critical micelle concentration (CMC) are all desired surfactant properties (Paria, 2008). Although anionic surfactants can precipitate, when used in combination with a non-ionic surfactant, they can lower precipitation and CMC values. Biosurfactants may be more biodegradable, resistant to $\mathrm{pH}$, salt, and temperature changes, and less expensive in some cases (West and Harwell, 1992). As a result, soil remediation often used both anionic and non-ionic surfactants. Surfactant classification and examples are summarized in Table 3.1.

Table 3.1: Classification and example of surfactants (Liu et al., 2019).

\begin{tabular}{|c|c|c|}
\hline Type & Category & Example \\
\hline \multirow[t]{3}{*}{ Anionic surfactant } & Sulfate & Sodium Lauryl Sulfate (SLS) \\
\hline & Sulfonate & $\begin{array}{c}\text { Sodium Dodecylbenzene } \\
\text { Sulfonate (SDBS) }\end{array}$ \\
\hline & Carboxylate & Sodium stearate \\
\hline \multirow[t]{3}{*}{ Cationic surfactant } & Amine salt & Priminox-43 \\
\hline & Quaternary ammonium & $\begin{array}{l}\text { Cetyltrimethylammonium } \\
\text { bromide }\end{array}$ \\
\hline & Heterocycle & Isothan Q-15 \\
\hline \multirow[t]{4}{*}{ Non-ionic surfactant } & Polyoxyethylene & $\begin{array}{c}\text { Alkylphenol ethoxylates } \\
\text { (APEO) }\end{array}$ \\
\hline & Polyalcohol & Span-80 \\
\hline & Alkanolamide & Coconut diethanolamide \\
\hline & Polyether & OP-20 \\
\hline \multirow[t]{4}{*}{ Amphoteric surfactant } & Aminopheno & $\begin{array}{c}\text { Sodium } \\
\text { Lauraminopropionate }\end{array}$ \\
\hline & Betaine & $\begin{array}{l}\text { Dodecyl ethoxysulfonyl } \\
\text { betaine }\end{array}$ \\
\hline & Imidazoline & Miranol CM \\
\hline & Amine oxide & $\begin{array}{l}\text { Octadecyl dihydroxyethyl } \\
\text { amine oxide }\end{array}$ \\
\hline
\end{tabular}




\subsection{Non-ionic surfactant}

Non-ionic surfactants are extensively utilized in field washing operations because they are ecologically friendly and economically effective. They have lower CMC values and a weaker ability to flocculate clay particles in the soil than ionic surfactants (Volkering et al., 1997). Other non-ionic surfactant properties change as temperature rises, such as CMC decreasing monotonically, adsorption on solid and liquid surfaces increasing and adsorbed layers becoming more compact, interaction between surfactant-covered surfaces changing from repulsive to attractive, colloidal stability being lost, and microemulsions changing structure from oil-in-water to water-ionize (Lindman et al., 2016).

The most commonly used non-ionic surfactants for soil remediation are such as Triton X-100, Triton X-114, Brij-35, and Tween-80. Tween series (polysorbates) non-ionic surfactants have applications in food, biotechnical, pharmaceutical, industrial, domestic, chemical, and biochemical fields. Tweens with various long chain saturated carboxylic acids, from lauric to stearic, and unsaturated oleic acid have 20 ethylene oxide groups connected to the sorbitol headgroup in commercially available Tweens (Szymczyk and Taraba, 2017). Because of their biodegradability and low toxicity, they have a wide range of applications (Lee et al., 2005). Triton X-114 is a surfactant that has been extensively studied in cloud point extraction separation procedures.

\section{Methods for the removal of heavy metal from soil and water}

\subsection{Soil-washing process}

Contaminated soil must be rectified to reduce the risk to the environment. One of the most promising soil remediation procedures for heavy metal-contaminated samples is surfactant aided soil washing. In recent years, surfactants have been widely employed to remove heavy metals from soil. Surfactant enhanced soil washing has been shown to be a cost-effective method of remediation. The selection of appropriate surfactants and dosages is the first stage in the formulation of a washing process (Torres et al., 2005). Besides, soil washing is a typical method for removing pollutants that have become adsorbed on soil particles (Rongsayamanont et al., 2020). The washing efficiency of various surfactants for heavy metals in soil was reported in Table 4.1 
Table 4.1: Efficacy of various surfactants in removing heavy metals from soil (Liu et al., 2019).

\begin{tabular}{|c|c|c|}
\hline Surfactant Type & Heavy Metal & Effectiveness \\
\hline Saponin & $\mathrm{Pb}, \mathrm{Cu}, \mathrm{Zn}$ & $98 \%, 95 \%, 56 \%$ \\
\hline Saponin & $\mathrm{Zn}, \mathrm{Cd}$ & $85 \%-95 \%, 90 \%-100 \%$ \\
\hline Rhamnolipid & $\mathrm{Pb}, \mathrm{Cd}$ & $99.99 \%, 82.8 \%$ \\
\hline SLES & $\mathrm{Pb}, \mathrm{Cd}$ & $99.8 \%, 98.7 \%$ \\
\hline Texapon $\mathrm{N}-40$ & $\mathrm{Zn}, \mathrm{Cu}$ & $86.6 \%, 83.2 \%$ \\
\hline SDS+EDTA & $\mathrm{Cd}$ & $99.5 \%$ \\
\hline Saponin + EDDS & $\mathrm{Pb}, \mathrm{Cu}$ & $1 \%-2 \%$ \\
\hline EDTA +Citric acid + SDBS & $\mathrm{Pb}, \mathrm{Zn}, \mathrm{Cr}, \mathrm{Cu}, \mathrm{Ni}$ & $99.7 \%, 99.4 \%, 49.2 \%, 99.7 \%, 98.4 \%$ \\
\hline SDS & $\mathrm{Pb}$ & $61.67 \%$ \\
\hline EDTA & $\mathrm{Pb}$ & $89.65 \%$ \\
\hline EDTA + SDS & $\mathrm{Pb}$ & \\
\hline
\end{tabular}

Biodegradable non-ionic surfactants are extensively utilised in field washing operations because they are ecologically friendly and economically effective. They have lower CMC values and a weaker ability to flocculate clay particles in the soil than ionic surfactants (Mulligan et al., 2001). The surfactant should have a higher solubilizing activity for pollutants and a lower sorption to soil for effective soil cleansing. However, when it comes to surfactant recovery, a selective sorption capability versus contaminants on activated carbon would have a significant impact on the overall efficacy of the washing and recovery process (Ahn et al., 2008). In the soil washing process, the heavy metal removed from the soil will be determined using an atomic absorption spectrophotometer (AAS) to analyze the level of heavy metals such as $\mathrm{Cd}, \mathrm{Cu}, \mathrm{Zn}$ and $\mathrm{Pb}$.

\subsection{Cloud point extraction (CPE)}

Cloud point extraction (CPE) is a low-cost, environmentally friendly approach for preconcentrating and separating a wide range of analytes. It has several advantages over traditional liquid-liquid extraction (Samaddar and Sen, 2014). Non-ionic surfactants are the most common 
in CPE. They have a low ionisation and are water soluble. Commercial non-ionic surfactants include the Triton X series, which includes Triton X-100 (polyoxyethylene-9.5-octylphenoxy ether) and Triton X-114 (polyoxyethylene-9.5-octylphenoxy ether). They are polyoxymethylene in nature, with the typical formula $\mathrm{RO}\left(\mathrm{CH}_{2} \mathrm{CH}_{2} \mathrm{O}\right)_{n} \mathrm{H}$. They cannot operate as Bronsted acids in aqueous conditions since the proton is also not ionizable. They can be used in CPE by themselves or in combination with another ionic surfactant. Furthermore, surfactant concentration is crucial in CPE. Phase separation is only achievable in a narrow concentration range. As the surfactant concentration rises, the extraction efficiency decreases due to a decrease in the preconcentration factor. A decreased surfactant concentration, on the other hand, results in analyte absorption that is insufficient (Paleologos et al., 2005).

In Figure 4.1, the overall approach for cloud point extraction is conceptualised and illustrated, and in Figure 4.2, the process is demonstrated. Table 4.2, on the other hand, lists the metal (M), surfactant $(\mathrm{S})$, heating time $(\mathrm{t})$, temperature $(\mathrm{T})$, acceptable reference $(\mathrm{R})$, centrifugation time $(\mathrm{Y})$, and chelating agent $(\mathrm{C})$ for various $\mathrm{CPE}$.

Table 4.2: Conditions for different metal ion cloud point extraction (Samaddar and Sen, 2014).

\begin{tabular}{|c|c|c|c|c|c|c|}
\hline $\begin{array}{l}\text { Meta } \\
\text { I (M) }\end{array}$ & $\begin{array}{l}\text { Surfactan } \\
\text { t (S) }\end{array}$ & Complexing agent $(\mathrm{C})$ & $\begin{array}{l}\text { Temperatur } \\
\text { e (T) }\end{array}$ & $\begin{array}{l}\text { Heatin } \\
\text { g time, } \\
t \text { (min) }\end{array}$ & $\begin{array}{l}\text { Centrifugin } \\
\mathrm{g} \text { time, } \mathrm{Y} \\
(\mathrm{min})\end{array}$ & $\begin{array}{l}\text { Reagent } \\
\text { (R) }\end{array}$ \\
\hline $\mathrm{Cu}$ & $\begin{array}{l}\text { Triton X- } \\
100\end{array}$ & Amino acid & $68^{\circ} \mathrm{C}$ & 10 & 5 & $\begin{array}{l}\text { Absolute } \\
\text { methano } \\
1\end{array}$ \\
\hline $\mathrm{Cu}$ & $\begin{array}{l}\text { Triton X- } \\
114\end{array}$ & $\begin{array}{l}\text { N,N'-bis(2-hydroxy } \\
\text { acetophenone)-1,2- } \\
\text { propanedimine(L) }\end{array}$ & $35^{\circ} \mathrm{C}$ & 15 & 10 & $\begin{array}{l}\mathrm{HNO}_{3} \text { in } \\
\text { methano } \\
1\end{array}$ \\
\hline $\mathrm{Cd}$ & $\begin{array}{l}\text { Triton X- } \\
114\end{array}$ & APDC & $45^{\circ} \mathrm{C}$ & 20 & 10 & Ethanol \\
\hline $\mathrm{Cd}$ & $\begin{array}{l}\text { Triton X- } \\
114\end{array}$ & Dithizone & $55^{\circ} \mathrm{C}$ & 20 & 10 & THF \\
\hline $\mathrm{Cd}$ & $\begin{array}{l}\text { Triton X- } \\
114\end{array}$ & Methyl green (MG) & $50^{\circ} \mathrm{C}$ & 15 & 10 & $\begin{array}{l}\mathrm{HNO}_{3} \text { in } \\
\text { methano } \\
1(1 \mathrm{~mol} \\
\left.\mathrm{L}^{-1}\right)\end{array}$ \\
\hline
\end{tabular}




\begin{tabular}{|c|c|c|c|c|c|c|}
\hline $\mathrm{Cd}$ & $\begin{array}{l}\text { Triton X- } \\
114\end{array}$ & Iodide, methyl green (MG) & $50^{\circ} \mathrm{C}$ & 15 & 10 & $\begin{array}{l}\mathrm{HNO}_{3} \text { in } \\
\text { methano } \\
1\end{array}$ \\
\hline $\mathrm{Pb}$ & $\begin{array}{l}\text { Triton X- } \\
114\end{array}$ & Dithizone, octanol & RT & 1 & - & $\begin{array}{l}\mathrm{HNO}_{3} \text { in } \\
\text { methano } \\
1(1 \mathrm{~mol} \\
\left.\mathrm{L}^{-1}\right)\end{array}$ \\
\hline $\mathrm{Pb}$ & $\begin{array}{l}\text { Triton X- } \\
114\end{array}$ & Brilliant cresyl blue (BCB) & $40^{\circ} \mathrm{C}$ & 30 & 10 & $\begin{array}{l}\mathrm{HNO}_{3} \text { in } \\
\text { methano } \\
1(1 \mathrm{~mol} \\
\left.\mathrm{L}^{-1}\right)\end{array}$ \\
\hline $\mathrm{Zn}$ & $\begin{array}{l}\text { Triton X- } \\
114\end{array}$ & $\begin{array}{l}\text { 2-methyl-8- } \\
\text { hydroxyquinoline(quinaldine) } \\
\text {, PAN }\end{array}$ & $70^{\circ} \mathrm{C}$ & 20 & 10 & $\begin{array}{l}\mathrm{HNO}_{3} \text { in } \\
\text { ethanol }\end{array}$ \\
\hline $\begin{array}{l}\mathrm{Al}, \\
\mathrm{Zn}\end{array}$ & $\begin{array}{l}\text { Triton X- } \\
114\end{array}$ & 8-HQ & $45^{\circ} \mathrm{C}$ & 10 & 7 & Ethanol \\
\hline $\begin{array}{l}\mathrm{Pb}, \\
\mathrm{Co}, \\
\mathrm{Cu}\end{array}$ & $\begin{array}{l}\text { Triton X- } \\
114\end{array}$ & $\begin{array}{l}\text { 1-Phenylthiosemicarbazide } \\
\text { (1-PTSC) }\end{array}$ & $50^{\circ} \mathrm{C}$ & 20 & 10 & $\begin{array}{l}\mathrm{HNO}_{3} \text { in } \\
\text { methano } \\
1\end{array}$ \\
\hline $\begin{array}{l}\mathrm{Fe}, \\
\mathrm{Cu}\end{array}$ & $\begin{array}{l}\text { Triton } \\
X-114\end{array}$ & Erichrome cyanine & $70^{\circ} \mathrm{C}$ & 15 & - & $\begin{array}{l}0.02 \mathrm{M} \\
\mathrm{H}_{2} \mathrm{SO}_{4} \\
\text { in } \\
\text { ethanol }\end{array}$ \\
\hline
\end{tabular}

Metal ion complexation with a suitable ligand is necessary for metal ion CPE, and the reaction is pH dependent (Pytlakowska et al., 2013). Azo dyes, dithiocarbamates, and dithizones are the most often used complexing agents in metal ion CPE. A ligandless CPE approach was developed for the removal of particular metal ions. Metal ion extraction into Tween 80 (Polyethylene glycol sorbitan monooleate) at $\mathrm{pH} 8.5$ was used to preconcentrate $\mathrm{Cd}^{2+}, \mathrm{Ni}^{2+}$, $\mathrm{Pb}^{2+}, \mathrm{Bi}^{3+}, \mathrm{Cu}^{+}, \mathrm{Cr}^{3+}$, and from food, water, and pharmaceutical samples (Mortada, 2020). For metal ion preconcentration from wastewater, cloud point extraction has been widely used. Cobalt and lead ions were recovered from fresh and wastewater samples using 8hydroxyquinoline as a complexing agent and Triton $\mathrm{X}-114$ as a non-ionic surfactant (Naeemullah et al., 2012). Aside from that, clouding has been observed in various zwitterionic and ionic surfactant concentrated aqueous salt solutions. At a given temperature, clouding, also known as coacervate phase behaviour or lower consolute behaviour, is a frequent physical 
change in amphiphilic homogeneous solutions that causes the solution to split into two surfactant-rich and surfactant-lean phases. In non-ionic surfactants, the cloud point (CP) or lower consolute temperature (LCT) is the temperature at which phase separation occurs. Clouding is responsible for the effective drying of micelle hydrophilic portions at higher temperatures. Surfactant micelles attract one another and form clusters as the cloud point temperature approaches (Samaddar and Sen, 2014).

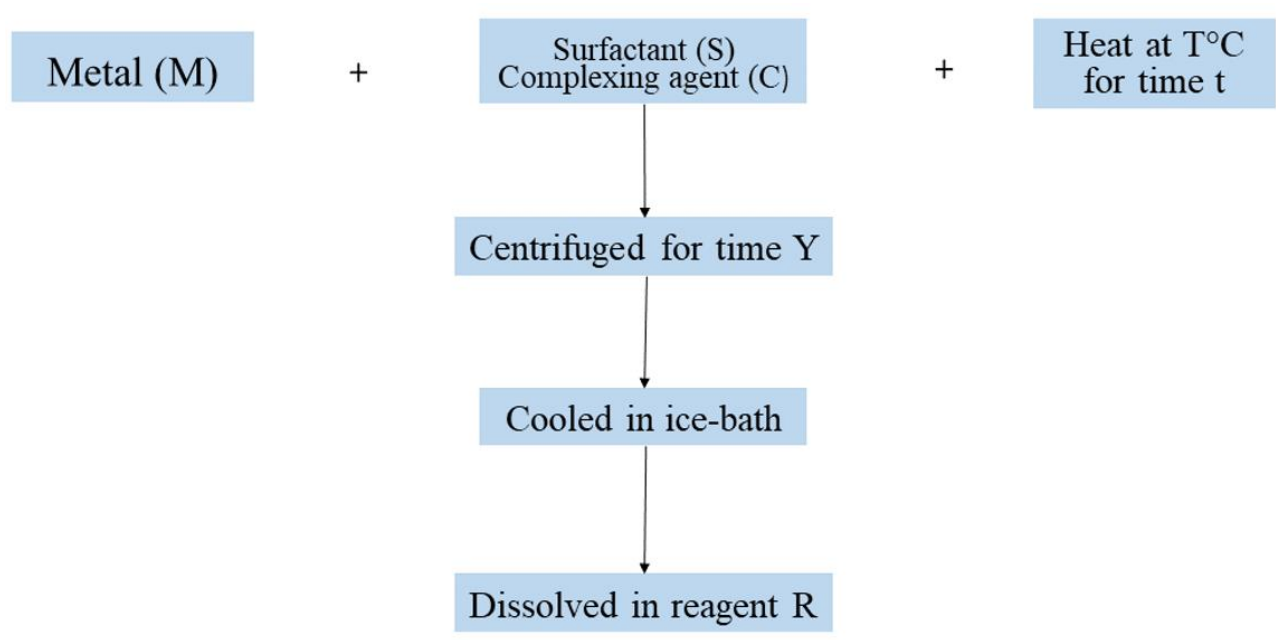

Figure 4.1: A flowchart depicting the general processes in cloud point extraction (Samaddar and Sen, 2014).

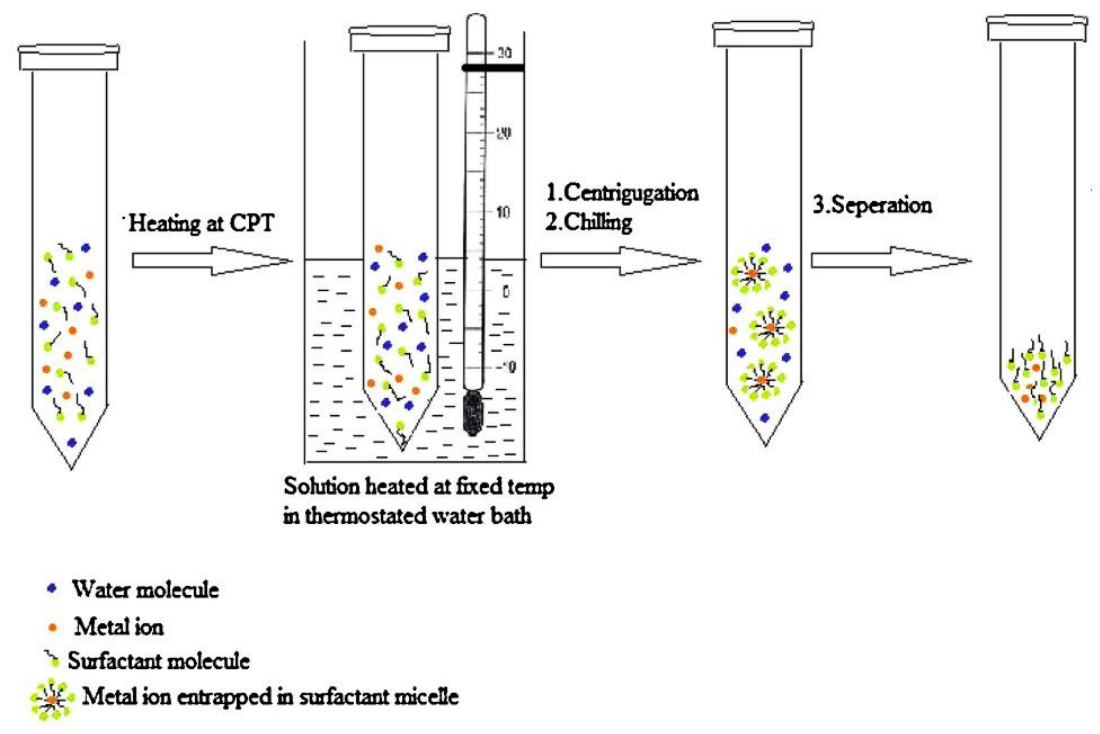

Figure 4.2: A schematic diagram of cloud point extraction (Samaddar and Sen, 2014). 


\section{Effect of parameters}

\subsection{Effect of pH}

The $\mathrm{pH}$ has been demonstrated to influence metal-chelate formation and extraction, as well as being a significant parameter in the CPE method. As a result, before going on to other parameters in the extraction operation, $\mathrm{pH}$ was improved first. Table 5.1 shows the CPE system parameters optimized where $\mathrm{pH} 4$ at temperature from $40{ }^{\circ} \mathrm{C}$ to $80{ }^{\circ} \mathrm{C}$ with the surfactant system $0.3 \%(\mathrm{v} / \mathrm{v})$ Triton $\mathrm{X}-114$, meanwhile $\mathrm{pH}$ value is 5.5 at temperature $40{ }^{\circ} \mathrm{C}, 1.25 \%(\mathrm{v} / \mathrm{v})$ Triton X-114 (Khan et al., 2010; Wang et al., 2010).

Table 5.1: CPE system parameters optimized

\begin{tabular}{|l|l|l|l|l|l|}
\hline $\begin{array}{l}\text { Type of } \\
\text { surfactant }\end{array}$ & Temperature & Salts & pH & $\begin{array}{l}\text { Surfactant } \\
\text { system }\end{array}$ & References \\
\hline Triton $\mathrm{X}-114$ & $40^{\circ} \mathrm{C}-80{ }^{\circ} \mathrm{C}$ & $\begin{array}{l}\mathrm{NaOH} \text { or } \\
\mathrm{HCl}\end{array}$ & 4 & $\begin{array}{l}0.3 \% \quad(\mathrm{v} / \mathrm{v}) \\
\text { Triton } \mathrm{X}-114\end{array}$ & $\begin{array}{l}(\text { Khan } \text { et al. } \\
2010)\end{array}$ \\
\hline Triton $\mathrm{X}-114$ & $40^{\circ} \mathrm{C}$ & - & 5.5 & $\begin{array}{l}1.25 \% \quad(\mathrm{v} / \mathrm{v}) \\
\text { Triton } \mathrm{X}-114\end{array}$ & $\begin{array}{l}\text { (Wang } \text { et al. } \\
2010)\end{array}$ \\
\hline
\end{tabular}

Lower $\mathrm{pH}$ values (below $\mathrm{pH}$ 5) indicate an acidic solution, resulting in a decreasing trend in extraction recovery. In hydrophobic micelles, analytes in acidic form solution have ionic properties, resulting in a minimal degree of analyte recovery. Because of the basic condition of the solution, the analytes appear to be deprotonated at higher $\mathrm{pH}$ levels (greater than $\mathrm{pH} 8$ ). As a result, separation is hampered, and analyte concentrations in the surfactant-rich phase decrease (Noorashikin et al., 2013). Aside from that, there have been some earlier research that show how $\mathrm{pH}$ affects heavy metal speciation and removal. The stability and mobility of copper, for example, have been shown to increase as $\mathrm{pH}$ falls. When the $\mathrm{pH}$ rises, the heavy metals form complexes with the hydroxide ions, changing the oxidation state of the heavy metal. As the $\mathrm{pH}$ rises above neutral, heavy metals produce particles that precipitate out of the water. As the $\mathrm{pH}$ rises, the oxidation state of chromium shifts from $\mathrm{Cr}(\mathrm{III})$, which is more stable, to $\mathrm{Cr}(\mathrm{VI})$, which is more toxic. 


\subsection{Effect of surfactant concentration}

Surfactant concentration is significant in phase separation because a lower concentration causes incomplete separation, whereas a larger concentration than the necessary amount increases the viscosity of the surfactant-rich phase while reducing its volume (Sohaimi et al., 2017). A study was done using CPE where the concentration of Triton $\mathrm{X}-114$ used for determining $\mathrm{Ag}^{+}$ions is $0.35 \%$ because it provides the best recovery at this concentration; above $0.4 \%$, the recovery drops significantly due to viscosity and increased volume of the micellar phase (Yang et al., 2017).

Figure 6.1 shows the effect of surfactant concentration in membrane phase on $\mathrm{Cd}(\mathrm{II})$ extraction efficiency at fixed concentrations of D2EHPA (1\% wt.) and $\mathrm{Cd}^{2+}(500 \mathrm{ppm})$ (Benderrag et al., 2019). In the previous study, non-ionic surfactant used is Triton X-100. Referring to the Figure 5.1, the removal of $\mathrm{Cd}^{2+}$ increases to about $98 \%$ when Triton $\mathrm{X}-100$ concentration in the membrane phase is $0.5 \%$ wt. and remains constant after this point. Previous research has shown that above this threshold, metal ion extraction slows, causing an increase in liquid membrane viscosity at high surfactant concentrations. As a result, the viscosity increased the resistance at the membrane interface, making the extraction kinetics unfavourable. Thus, the diffusivity of complexes in the organic phase decreases, lowering the mass transfer coefficient (Benderrag et al., 2019).

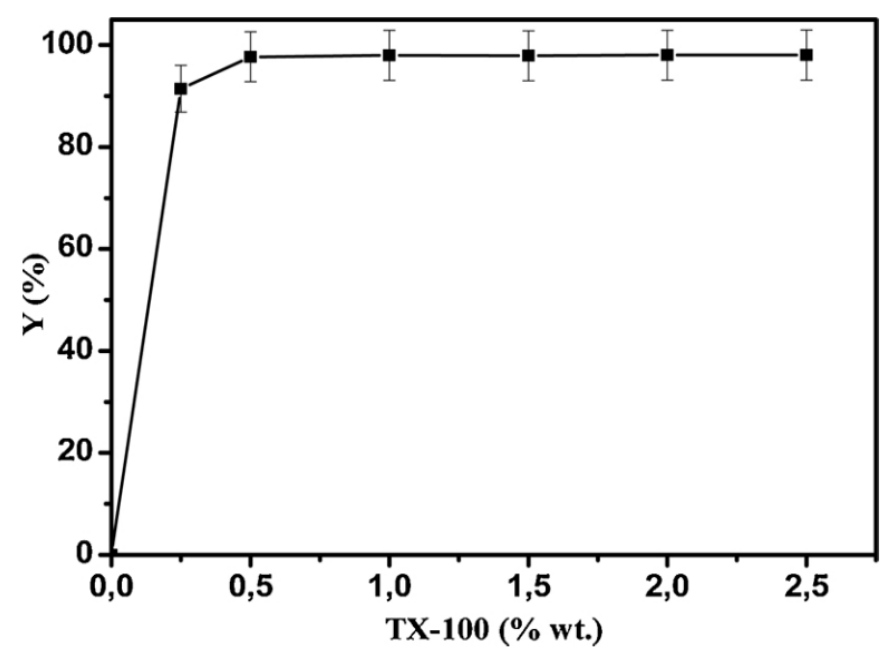

Figure 5.1: The effect of surfactant concentration on $\mathrm{Cd}^{2+}$ extraction (Benderrag $e$ al ., 2019). 


\subsection{Effect of time and temperature}

Another significant element to consider when examining the behaviour of heavy metals and their eventual elimination is temperature. Many of the mechanisms for heavy metal removal that have been found, such as surface complexation reactions and other forms of ion exchange, are improved at higher temperatures (Chen et al., 2010). To ensure easy and efficient phase separation with preconcentration, an appropriate incubation duration and equilibrium temperature are necessary. The formation of surfactant-rich phases is predominantly caused by surfactant behaviour (Sohaimi et al., 2017).

In the meanwhile, extraction times of less than 5 minutes are discouraged since phase separation is still incomplete and has only recently begun. As a result, the most effective extraction time for this procedure is between 5 and 10 minutes. Evaporation of the solution occurs at temperatures above $40{ }^{\circ} \mathrm{C}$, resulting in the loss of desirable analytes. Because the analytes are immobilized at low temperatures (below room temperature), there is relatively little separation. Surfactant was unable to perform adequately.

\subsection{Effect of natural organic matter (NOM)}

NOM is a term referring to a mixture of organic, water-insoluble components that can be found in a variety of settings, including water, sediment, and soil. The most common mechanism for NOM in soil, sediments, and natural waters is through humic chemicals, which contribute to the brownish-yellowish color of natural rivers. NOM is produced as a by-product of bacteria, algae, and aquatic plants in the aquatic environment, as well as from the breakdown of terrestrial plants (Sillanpää, 2015). Determining the exact impact of NOM on heavy metals can be difficult due to the large number of additional factors that determine how NOM impacts heavy metals, such as $\mathrm{pH}$, the humification of the specific NOM, and the oxidation state of the heavy metal.

Because of their acidic nature, NOM interact with heavy metals via a variety of mechanisms including as ion exchange, chelation, and surface adsorption (Reuter and Perdue, 1977). Previous study has shown that NOM can affect heavy metal removal, making it more difficult to determine heavy metal removal methods. 


\section{Conclusion}

The effectiveness of the non-ionic surfactant in removing heavy metals is found to be highly reliant on water and soil quality parameters such as $\mathrm{pH}$, surfactant concentration, time, and temperature, as well as the surfactant's characteristics. According to the research, heavy metals precipitate out in solid form as the $\mathrm{pH}$ goes above neutral. Furthermore, surfactant concentration is significant since a lower concentration results in an incomplete extraction, whereas a higher concentration than the needed amount increases the viscosity of the surfactant-rich phase while decreasing its volume. Lower temperatures below room temperature result in very little separation, and extraction time less than 5 minutes are discouraged since phase separation is said to be partial and has only recently begun. Finally, the presence of NOM can impair heavy metal removal, making it more difficult to select heavy metal removal methods. Based on these findings, it can be concluded that the removal of heavy metals from soil and water using non-ionic surfactants was effective using the cloud point extraction and soil washing methods under the right conditions.

\section{Acknowledgements}

Sincere appreciation was conveyed to University Industry Centre (UnIC) of Universiti Malaysia Sarawak (UNIMAS) for the industrial opportunity. This study was also supported by the Faculty of Resource Science and Technology, UNIMAS. 


\section{References}

Benderrag, A. Haddou, B., Daaou, M., Benkhedja, H., Bounaceur, B. and Kameche, M. (2019) 'Experimental and modeling studies on $\mathrm{Cd}$ (II) ions extraction by emulsion liquid membrane using Triton X-100 as biodegradable surfactant', Journal of Environmental Chemical Engineering, 7(3), p. 103166. doi: 10.1016/j.jece.2019.103166.

Chen, H., Zhao, J., Guoliang, D., Wu, J. and Yan, H. (2010) 'Adsorption characteristics of Pb(II) from aqueous solution onto a natural biosorbent, fallen Cinnamomum camphora leaves', Desalination, 262(1-3), pp. 174-182. doi: 10.1016/j.desal.2010.06.006.

Dube, A., Zbytniewski, R., Kowalkowski, T., Cukrowska, E.,and Buszewski, B. (2001) 'Adsorption and Migration of Heavy Metals in Soil', Polish Journal of Environmental Studies, 10(1), pp. 1-10.

Herschy, R. W. (2012) 'Water quality for drinking: WHO guidelines', Encyclopedia of Earth Sciences Series, pp. 876-883. doi: 10.1007/978-1-4020-4410-6_184.

Jaiswal, A., Verma, A. and Jaiswal, P. (2018) 'Detrimental effects of heavy metals in soil, plants, and aquatic ecosystems and in humans', Journal of Environmental Pathology, Toxicology and Oncology, 37(3), pp. 183-197. doi: 10.1615/JEnvironPatholToxicolOncol.2018025348.

Joseph, L. Jun, B., Flora, J., Park, C. M., Yoon, Y. (2019) 'Removal of heavy metals from water sources in the developing world using low-cost materials: A review', Chemosphere, 229, pp. 142-159. doi: 10.1016/j.chemosphere.2019.04.198.

Khan, S., Kazia, T. G, Baig, J. A., Kolachi, N. A., Afridi, H. I., Wadhwaa, S. K., Shah, A. Q., Kandhro, G. A., Shah, F. (2010) 'Cloud point extraction of vanadium in pharmaceutical formulations, dialysate and parenteral solutions using 8-hydroxyquinoline and nonionic surfactant', Journal of Hazardous Materials, 182(1-3), pp. 371-376. doi: 
10.1016/j.jhazmat.2010.06.042.

Lee, D. H., Kim, E. S. and Chang, H. W. (2005) 'Effect of Tween surfactant components for remediation of toluene-contaminated groundwater', Geosciences Journal, 9(3), pp. 261267. doi: 10.1007/BF02910586.

Lee, S. M., Lee, J. Y., Yu, H. P. and Lim, J. C. (2016) 'Synthesis of environment friendly nonionic surfactants from sugar base and characterization of interfacial properties for detergent application', Journal of Industrial and Engineering Chemistry, 38, pp. 157-166. doi: 10.1016/j.jiec.2016.04.019.

Lindman, B., Medronho, B. and Karlström, G. (2016) 'Clouding of nonionic surfactants', Current Opinion in Colloid and Interface Science, 22, pp. 23-29. doi: 10.1016/j.cocis.2016.01.005.

Liu, J., Xue, J., Yuan, D., Wei, X. and Su, H. (2019) 'Surfactant Washing to Remove Heavy Metal Pollution in Soil: A Review', Recent Innovations in Chemical Engineering (Formerly Recent Patents on Chemical Engineering), 13(1), pp. 3-16. doi: 10.2174/2405520412666190912151737.

Mortada, W. I. (2020) 'Recent developments and applications of cloud point extraction: A critical review', Microchemical Journal, 157(June), p. 105055 . doi: 10.1016/j.microc.2020.105055.

Mulligan, C. N., Yong, R. N. and Gibbs, B. F. (2001) 'Surfactant-enhanced remediation of contaminated soil: A review', Engineering Geology, 60(1-4), pp. 371-380. doi: 10.1016/S0013-7952(00)00117-4.

Paria, S. (2008) 'Surfactant-enhanced remediation of organic contaminated soil and water', Advances in Colloid and Interface Science, 138(1), pp. 24-58. doi: 10.1016/j.cis.2007.11.001. 
Reuter, J. H. and Perdue, E. M. (1977) 'Importance of heavy metal-organic matter interactions in natural waters', Geochimica et Cosmochimica Acta, 41(2), pp. 325-334. doi: 10.1016/0016-7037(77)90240-X.

Samaddar, P. and Sen, K. (2014) 'Cloud point extraction: A sustainable method of elemental preconcentration and speciation', Journal of Industrial and Engineering Chemistry, 20(4), pp. 1209-1219. doi: 10.1016/j.jiec.2013.10.033.

Shanbehzadeh, S., Dastjerdi, M. Z., Hassanzadeh, A. and Kiyanizadeh., T. (2014) 'Heavy metals in water and sediment: A case study of Tembi River', Journal of Environmental and Public Health, 2014. doi: 10.1155/2014/858720.

Sillanpää, M. (2015) General Introduction, Natural Organic Matter in Water: Characterization and Treatment Methods. Elsevier Inc. doi: 10.1016/B978-0-12-801503-2.00001-X.

Sohaimi, N. M., Suda, N., Aziz, H. Z., Zaini, S. R. M., Kandasamy, S. and Suresh, K. (2017) 'the Application of Cloud Point Extraction', 12(1), pp. 79-95.

Szymczyk, K. and Taraba, A. (2017) 'Properties of aqueous solutions of nonionic surfactants, Triton X-114 and Tween 80, at temperatures from 293 to $318 \mathrm{~K}$ : Spectroscopic and ultrasonic studies', Chemical Physics, 483-484, pp. 96-102. doi: 10.1016/j.chemphys.2016.11.015.

Torres, L. G., Aguirre, A. L., Verdejo, A. and Iturbe, R. (2005) 'Enhanced soil-washing treatment for soils which are highly contaminated with crude oil', WIT Transactions on Ecology and the Environment, 81, pp. 541-550.

Varshney, K. G., Rafiquee, M. Z. A. and Somya, A. (2007) 'Effect of surfactants on the adsorption behaviour of tin(IV) phosphate, cation exchanger for alkaline earths and heavy metal ions', Colloids and Surfaces A: Physicochemical and Engineering Aspects, 301(1-3), pp. 224- 
228. doi: 10.1016/j.colsurfa.2006.12.061.

Volkering, F., Breure, A. M. and Rulkens, W. H. (1997) 'Microbiological aspects of surfactant use for biological soil remediation', Biodegradation, 8(6), pp. 401-417. doi: 10.1023/A:1008291130109.

Wang, L. L., Wang, J. Q., Zheng, Z. X. and Xiao, P. (2010) 'Cloud point extraction combined with high-performance liquid chromatography for speciation of chromium(III) and chromium(VI) in environmental sediment samples', Journal of Hazardous Materials, 177(1-3), pp. 114-118. doi: 10.1016/j.jhazmat.2009.12.003.

West, C. C. and Harwell, J. H. (1992) 'Surfactants and Subsurface Remediation', Environmental Science and Technology, 26(12), pp. 2324-2330. doi: 10.1021/es00036a002.

Yang, X., Jia, Z., Yang, X., Li, G. and Liao, X. (2017) 'Cloud point extraction-flame atomic absorption spectrometry for pre-concentration and determination of trace amounts of silver ions in water samples', Saudi Journal of Biological Sciences, 24(3), pp. 589-594. doi: 10.1016/j.sjbs.2017.01.030. 